\title{
HUBUNGAN MOTIVASI UNTUK MENJADI PERAWAT PROFESIONAL DENGAN HASIL BELAJAR PADA MAHASISWA SEMESTER V TINGKAT III AKADEMI KEPERAWATAN PEMERINTAH KABUPATEN BELU TAHUN AJARAN 2014/2015
}

\author{
Antonius Edi dasi Seran*) \\ Gaudentiana Un Bria**) \\ Christina Marina Meo**) \\ *)Rumah Sakit Anak dan Bunda (RSAB) Harapan Kita Jakarta. J1. Letjen S. Parman Street No. \\ Kav.87, RT.1/RW.8. Slipi, Jakarta Barat. Phone: 081246226154. Email: edi_seran@ yahoo.com. \\ **) Akademi Keperawatan Pemerintah Kabupaten Belu, Jl. Wehor Kabuna Haliwen Atambua \\ Nusa Tenggara Timur. Post: 85711.
}

\begin{abstract}
ABSTRAK
Motivasi merupakan salah satu faktor yang sangat berpengaruh bagi seorang mahasiswa karena motivasi juga ikut menentukan keberhasilan mahasiswa baik selama mengikuti pendidikan maupun setelah selesai mengikuti pendidikan. Penelitian ini dilakukan untuk mencari hubungan motivasi untuk menjadi perawat profesional dengan hasil belajar pada mahasiswa semester $\mathrm{V}$ Akper Pemkab Belu TA 2014/2015. Penelitian ini menggunakan metode cross-sectional kuantitatif. Analisis data menggunakan uji univarat dan bivariat. Pengujian menggunakan chisquare secara komputerisasi. Hasil analis univariat: 57.9\% mahasiswa memiliki motivasi intrinsik rendah, 52.9\% mahasiswa memiliki motivasi ekstrinsik tinggi untuk menjadi, 52.1\% mahasiswa memiliki motivasi yang rendah, $47.9 \%$ mahasiswa memiliki motivasi yang tinggi, 96.7\% mahasiswa memiliki rentang IP dengan kategori sangat memuaskan. Hasil analisis bivariat bahwa tidak ada hubungan antara motivasi intrinsik, ekstrinsik, dan motivasi untuk menjadi perawat profesional dengan hasil belajar.
\end{abstract}

Kata Kunci : Motivasi, Perawat profesional, Hasil belajar 


\title{
RELATIONSHIP OF MOTIVATION TO BEING A NURSING PROFESSIONAL WITH LEARNING OUTCOMES IN SEMESTER V STUDENTS LEVEL III BELU REGENCY NURSING ACADEMY 2014/2015 ACADEMIC YEAR
}

\author{
Antonius Edi Tie Seran*) \\ Gaudentiana Un Bria*) \\ Christina Marina Meo*) \\ *)Rumah Sakit Anak dan Bunda (RSAB) Harapan Kita Jakarta. Letjen S. Parman Street No. Kav. 87, \\ RT.1/RW.8. Slipi, West Barat. Phone: 081246226154.Email: edi_seran@yahoo.com \\ **) Belu Regency Government Nursing Academy, Jl. Wehor Kabuna Haliwen Atambua East Nusa \\ Tenggara. Post: 85711.
}

\begin{abstract}
Motivation is one of the factors that is very influential for a student because motivation also determines the success of students both during education and after completing education. This research was conducted to find the relationship of motivation to become a professional nurse with learning outcomes in the fifth semester students of Akper Belu Regency FY 2014/2015. This study uses quantitative crosssectional methods. Data analysis using univariate and bivariate tests. Tests use computerized chi-square. Univariate analysts results: $57.9 \%$ of students have low intrinsic motivation, $52.9 \%$ of students have high extrinsic motivation to be, $52.1 \%$ of students have low motivation, $47.9 \%$ of students have high motivation, $96.7 \%$ of students have IP ranges with very satisfying categories. bivariate analysis that there is no relationship between intrinsic, extrinsic, and motivation to become professional nurses with learning outcomes.
\end{abstract}

Keywords: Motivation, professional nurses, learning outcomes 


\section{PENDAHULUAN}

Seiring dengan perkembangan ilmu pengetahuan dan teknologi (IPTEK), pendidikan di Indonesia juga semakin maju dan berkembang termasuk dibidang keperawatan. Dimana pendidikan DIII Keperawatan sebagai salah satu lembaga pendidikan yang akan menghasilkan lulusan tenaga keperawatan yang professional pemula diharapkan mampu melakukan praktek keperawatan secara mandiri dan mampu bersaing dalam lainnya yang pada akhirnya akan dinyatakan sebagai berhasil atau gagal.

Keberhasilan yang dicapai oleh seseorang dinyatakan dalam hasil belajar. Hasil belajar inilah yang nantinya akan menggambarkan kemampuan professional mereka dimasa mendatang setelah menjadi perawat. Salah satu permasalahan di Akper Pemkab Belu yaitu masih terdapat beberapa mahasiswa yang memiliki nilai indeks prestasi belajar yang rendah. Bila dibiarkan dan tidak diperhatikan secara serius maka akan berpengaruh terhadap kemampuan lulusan tenaga perawat dalam melakukan pelayanan kesehatan .

Salah satu kondisi yang memungkinkan rendahnya indeks prestasi peserta didik adalah motivasi atau panggilan jiwa untuk menjadi perawat. Pada mulanya mereka yang masuk jenjang pendidikan DIII keperawatan, terdorong oleh karena keinginan yang besar ingin menjadi seorang perawat sehingga dengan keinginan yang besar untuk menjadi perawat tersebut mampu mereka lakukan tugas-tugas keperawatan dengan baik dan benar. Namun perkembangannya dewasa ini sangatlah berbeda, dimana mereka yang memasuki pendidikan DIII keperawatan tidak lagi didasari atas adanya motivasi atau panggilan jiwa untuk menjadi perawat, akan tetapi lebih banyak berorientasi karena ingin secepatnya mendapatkan pekerjaan .

Munculnya berbagai permasalahan yang berkaitan dengan kurangnya kualitas dari lulusan DIII Keperawatan dewasa ini, berawal dari sistem seleksi penerimaan peserta didik yang kurang memperhatikan unsur motivasi dari para calon peserta didik itu sendiri karena lebih banyak mengandalkan seleksi tes kognitif pada ujian tulis. Selain itu faktor desakan orang tua yang memaksa putra-putrinya untuk masuk DIII keperawatan. Dimana pada dasarnya putra-putrinya tidak memiliki kemauan untuk menggeluti profesi keperawatan. Akademi Keperawatan Pemerintah Kabupaten Belu merupakan salah satu institusi Pendidikan DIII Keperawatan yang sejak tahun 2001 telah menerima mahasiswa dengan latar belakang pendidikan tamatan atau lulusan SLTA/SMA dengan harapan agar mampu menghasilkan lulusan perawat professional sesuai yang diharapkan. Untuk mencapai tujuan tersebut dan menyikapi berbagai fenomena yang terjadi diatas maka penulis mencoba untuk menata sistem penerimaan mahasiswa baru dengan berbagai cara dan teknik yang memadai sehingga mampu mendapatkan calon peserta didik yang siap mengabdikan dirinya dalam profesi keperawatan secara tulus dan ikhlas.

Dari hasil observasi pada bagian Akademi Keperawatan Pemerintah Kabupaten Belu bahwa indeks prestasi yang diperoleh pada tahun akademik 2013/2014 Tingkat II IP tertinggi 3,85 dan terendah 2,14. Berdasarkan data tersebut diatas bahwa masih ada nilai yang tidak mencapai standar yang telah ditetapkan institusi/dosen sehingga harus mengikuti ujian perbaikan ataupun semester pendek. Apabila hal ini tidak diperhatikan maka akan mengakibatkan bertambahnya jumlah 
mahasiswa yang memperoleh hasil belajar dibawah standar kelulusan

Salah satu hambatan dalam belajar yang dialami oleh mahasiswa adalah motivasi.Motivasi memegang peranan yang besar bagi setiap orang terutama dalam upaya memperoleh hasil dari sebuah usaha dalam hal ini adalah belajar. Untuk itu, peneliti tertarik untuk membahas salah satu faktor yang dianggap sangat berpengaruh terhadap hasil belajar yaitu motivasi. Dimana motivasi merupakan aspek yang sangat menentukan terhadap keberhasilan mahasiswa baik selama mengikuti pendidikan maupun setelah selesai mengikuti pendidikan. Oleh karena itu penulis terdorong untuk mengangkat judul" Hubungan Motivasi Untuk Menjadi Perawat Profesional Dengan Hasil Belajar Pada Mahasiswa Tingkat III Semeter V Akademi Keperawatan Pemerintah Kabupaten Belu Tahun 2014/2015?”

\section{METODOLOGI PENELITIAN}

Dalam penelitian ini merupakan penelitian deskriptif analitik korelasi dengan pendekatana cross sectional dengan tujuan untuk menganalisis hubungan antara motivasi untuk menjadi perawat profesional dengan hasil belajar pada mahasiswa semester V Akademi Keperawatan Kabupaten Belu. Populasi pada penelitian ini adalah mahasiswa tingkat III Semester V Akademi Keperawatan Kabupaten Belu Tahun Ajaran 2014/2015, dengan teknik total sampling, diperoleh sampel sebanyak 133 orang yang memenuhi kriteria inklusi sebagai berikut: mahasiswa yang bersedia menjadi responden; mahasiswa tingkat III semester V Akademi Keperawatan Kabupaten Belu Tahun Ajaran 2014/2015 yang telah mengikuti yudisium pada semester tersebut. Alat pengumpulan data menggunakan kuisioner dan lembar observasi untuk mendapatkan nilai IP semester. Responden mengisi kuisioner yang disebarkan, sedangkan untuk nilai IP diperoleh dari bagian evaluasi Akademi Keperawatan Pemkab Belu. Teknik analisa menggunakan univariat dan bivariat chi square untuk mengetahui apakah variabel independen berhubungan dengan variabel dependen.

\section{HASIL DAN PEMBAHASAN}

Disini akan diuraikan penelitian tentang "hubungan motivasi mahasiswa untuk menjadi perawat profesional dengan hasil belajar di Akademi keperawatan Pemerintah Kabupaten Belu”. Responden penelitian ini adalah seluruh mahasiswa tingakt III semester V Tahun Ajaran 2014/2015, jumlah responden yang terlibat dalam penelitian ini adalah sebanyak 121 responden.

\section{a. Hasil Penelitian}

Laporan hasil penelitian akan disususn menjadi beberapa bagian, menurut data demografi yang telah digolongkan sebelumnya yaitu jenis kelamin, usia, dan agama, motivasi intrinsik mahasiswa untuk menjadi perawat profesional, motivasi ekstrinsik mahasiswa untuk menjadi perawat profesional, hasil belajar mahasiswa Akper Belu, hubungan motivasi intrinsik untuk menjadi perawat profesional dengan hasil belajar, hubungan motivasi ekstrinsik untuk menjadi perawat profesional dengan hasil belajar, hubungan motivasi untuk menjadi perawat profesional dengan hasil belajar. 


\section{b. Analisa Univariat}

Analisa ini bertujuan untuk mendeskripsikan karakteristik responden yang meliputi umur, jenis kelamin, agama, motivasi intrinsik, motivasi ekstrinsik dan hasil belajar. Analisa univariat ini dikelompokkan berdasarkan jenis data yang dimiliki oleh masing-masing sub variabel yang terbagimenjadi data kategorik dan numerik.

Tabel 1

Distribusi Responden Berdasarkan Jenis Kelamin dan Agama

Bagi Mahasiswa Semester V TA 2014/2015 Akper Pemkab Belu Januari, 2015 ( $\mathrm{N}=121)$

\begin{tabular}{cccc}
\hline Variabel & Kategori & f & Persentasi \\
\hline Jenis & Laki-laki & 24 & 19.8 \\
\cline { 2 - 4 } Kelamin & Perempuan & 97 & 80.2 \\
\cline { 2 - 4 } & Total & 121 & 100 \\
\hline Agama & Katholik & 107 & 88.4 \\
\cline { 2 - 4 } & Protestan & 11 & 9.1 \\
\cline { 2 - 4 } & Islam & 2 & 1.7 \\
\cline { 2 - 4 } & Hindu & 1 & 0.8 \\
\cline { 2 - 4 } & Budha & 0 & 0 \\
\cline { 2 - 4 } & Total & 121 & 100 \\
\hline
\end{tabular}

Hasil analisis berdasarkan tabel 1 diatas dapat dilihat bahwa proporsi responden berjenis kelamin perempuan sebanyak $80.2 \%$ (97 orang) dan laki-laki sebanyak $19.8 \%$ (24 orang). Berdasarkan agama terdapat $88.8 \%$ (107 orang) beragama Katholik, $9.1 \%$ (11 orang) beragama Protestan, $1.7 \%$ (2 orang) beragama Islam dan $0.8 \%$ (1 orang) beragama Hindu, sedangkan agama Budha $0 \%$.
Tabel 2

Distribusi Rata-Rata Umur Mahasiswa Semester V

Akper Pemkab Belu TA 2014/2015 Januari, 2015 ( $N=121)$

\begin{tabular}{ccccc}
\hline Variabel & Mean & SD & $\begin{array}{c}\text { Min- } \\
\text { Maks }\end{array}$ & $\begin{array}{c}95 \% \\
\text { CI }\end{array}$ \\
\hline Umur & 22.27 & 2.952 & $19-$ & 21.74 \\
& & & 36 & - \\
& & & & 22.80 \\
\hline
\end{tabular}

Berdasarkan hasisl analisis pada tabel 2 diketahui rata-rata umur responden secara keseluruhan adalah 22.27 tahun (95\% CI 21.74 - 22.80), dengan standar deviasi 2.952. Umur termuda adalah 19 tahun dan tertua adalah 36 tahun. Dari hasil estimasi interval dapat disimpulkan bahwa 95\% diyakini bahwa rata-rata umur Mahasiswa Semester V Akper Pemkab Belu TA 2014/2015 adalah diantara 21.74 sampai dengan 22.80 tahun.

Tabel 3

Motivasi Intrinsik Untuk Menjadi Perawat Profesional Pada Mahasiswa Semester V Akper Pemkab Belu TA 2014/2015

Januari, 2015 ( $\mathrm{N}=121)$

\begin{tabular}{llll}
\hline Variabel & Kategori & Jumlah & Presentase \\
\hline $\begin{array}{l}\text { Motivasi } \\
\text { Intrinsik }\end{array}$ & Rendah & 70 & $57,9 \%$ \\
\hline & Tinggi & 51 & $42,1 \%$ \\
\hline & Total & 121 & $100 \%$ \\
\hline
\end{tabular}

Berdasarkan tabel diatas, dapat dilihat bahwa motivasi intrinsik mahasiswa Semester V Tahun Ajaran 2014/2015 Akper Pemkab Belu TA 2014/2015 untuk menjadi perawat profesional tergolong rendah yaitu 70 responden $(57.9 \%)$ dan sisanya yaitu 51 responden $(42.1 \%)$ responden memiliki 
motivasi intrinsik yang tinggi untuk menjadi perawat professional

Tabel 4

Motivasi Ekstrinsik Untuk Menjadi

Perawat Profesional Pada Mahasiswa

Semester V Akper Pemkab Belu TA 2014/2015

Januari, $2015(\mathrm{~N}=121)$

\begin{tabular}{llll}
\hline Variabel & $\begin{array}{l}\text { Kategor } \\
\text { i }\end{array}$ & $\begin{array}{l}\text { Frekuens } \\
\text { i }\end{array}$ & $\begin{array}{l}\text { Persentase( } \\
\text { \%) }\end{array}$ \\
\hline Motivasi & Rendah & 57 & 47.1 \\
\cline { 2 - 4 } $\begin{array}{l}\text { Ekstrinsi } \\
\text { k }\end{array}$ & Tinggi & 64 & 52.9 \\
\hline & & & \\
\hline
\end{tabular}

Berdasarkan tabel 4 dapat dilihat bahwa Mahasiswa Semester V Akper Pemkab Belu Tahun Ajaran 2014/2015 memiliki motivasi ekstrinsik yang tinggi untuk menjadi perawat profesional yaitu sebesar 52.9\% (64 orang), sedangkan $47.1 \%$ (57 orang) lainnya memiliki motivasi ekstrinsik yang rendah untuk menjadi perawat profesional.

\section{Tabel 5}

Motivasi Untuk Menjadi Perawat Profesional Pada Mahasiswa Semester V Akper Pemkab Belu TA 2014/2015 Januari, 2015 ( $N=121)$

\begin{tabular}{llll}
\hline $\begin{array}{l}\text { Variab } \\
\text { el }\end{array}$ & $\begin{array}{l}\text { Katego } \\
\text { ri }\end{array}$ & $\begin{array}{l}\text { Frekuen } \\
\text { si }\end{array}$ & $\begin{array}{l}\text { Persentase( } \\
\text { \%) }\end{array}$ \\
\hline Motiva \\
si & Rendah & 63 & 52.1 \\
\cline { 2 - 4 } & Tinggi & 58 & 47.9 \\
\hline & Total & 121 & 100 \\
\hline
\end{tabular}

Berdasarkan tabel 5 dapat diketahui bahwa Mahasiswa Semester V Akper Pemkab Belu Tahun Ajaran 2014/2015 memiliki motivasi yang rendah untuk menjadi perawat profesional yaitu sebesar $52.1 \% \quad(63$ orang). Namun terdapat $47.9 \% \quad$ (58 orang) memiliki motivasi yang tinggi untuk menjadi perawat profesional.

Tabel 6

Hasil Belajar Mahasiswa Semester V Akper Pemkab Belu

Tahun Ajaran 2014/2015 Januari, 2015 ( $\mathrm{N}=121)$

\begin{tabular}{cccc}
\hline Variabel & Kategori & F & Persentasi \\
\hline Hasil & Memuaskan & 3 & 2,5 \\
\cline { 2 - 4 } Belajar & $\begin{array}{c}\text { Sangat } \\
\text { Memuaskan }\end{array}$ & 117 & 96,7 \\
& Cumlaude & 1 & 0,8 \\
\hline & Total & 121 & 100 \\
\hline
\end{tabular}

Berdasarkan tabel 6 dapat dilihat bahwa Hasil Belajar Mahasiswa Semester V Akper Pemkab Belu Tahun Ajaran 2014/2015 berturut-turut sebagai berikut: mahasiswa yang memiliki hasil belajar sangat memuaskan sebanyak 96.7\% (117 orang), dan terdapat $2.5 \%$ (3 orang) yang memiliki hasil belajar yang memuaskan, sedangkan yang memiliki hasil belajar cumlaude terdapat $0.8 \%$ (1 orang).

\section{c. Analisa Bivariat}

Pada bagian ini akan dilakukan analisis untuk mengetahui hubungan antara variabel dependen dan independen. 


\section{Tabel 4.7}

Hubungan Antara Motivasi Intrinsik Untuk Menjadi Perawat Profesional Dengan Hasil Belajar Pada Mahasiswa Semester V Akper

Pemkab Belu TA 2014/2015 Januari, $2015(\mathrm{~N}=121)$

*Bermakna pada $\alpha<0,05$ menjadi perawat profesional dengan hasil belajar bagi Mahasiswa Semester V Akper Pemkab Belu TA 2014/2015. Artinya Ho gagal ditolak.

Pada bagian sub variabel motivasi ekstrinsik yang dihubungkan dengan hasil belajar menunjukkan bahwa 41 orang $(73.2 \%)$ mahasiswa yang memiliki motivasi

\begin{tabular}{|c|c|c|c|c|c|c|c|c|c|}
\hline \multirow{3}{*}{ Variabel } & \multicolumn{6}{|c|}{ Hasil Belajar } & \multicolumn{2}{|c|}{ Total } & \multirow[t]{3}{*}{ P Value } \\
\hline & \multicolumn{2}{|c|}{ Memuaskan } & \multicolumn{2}{|c|}{$\begin{array}{c}\text { Sangat } \\
\text { Memuaskan }\end{array}$} & \multicolumn{2}{|c|}{ Cumlaude } & & & \\
\hline & $\mathrm{N}$ & $\%$ & $\mathrm{~N}$ & $\%$ & $\mathrm{~N}$ & $\%$ & $\mathrm{~N}$ & $\%$ & \\
\hline Motivasi Intrinsik & & & & & & & & & 0.418 \\
\hline Rendah & 19 & 27.1 & 50 & 71.4 & 1 & 1.4 & 70 & 57.85 & \\
\hline Tinggi & 10 & 19.6 & 41 & 80.4 & 0 & 0 & 51 & 42.15 & \\
\hline Total & 29 & 24 & 91 & 75.2 & 1 & 0.8 & 121 & 100 & \\
\hline Motivasi Ekstrinsik & & & & & & & & & 0.532 \\
\hline Rendah & 15 & 26.8 & 41 & 73.2 & 0 & 0 & 56 & 46.28 & \\
\hline Tinggi & 14 & 21.5 & 50 & 76.9 & 1 & 1.5 & 65 & 53.72 & \\
\hline Total & 29 & 24 & 91 & 75.2 & 1 & 0.8 & 121 & 100 & \\
\hline Motivasi Mahasiswa & & & & & & & & & 0.572 \\
\hline Rendah & 16 & 25.4 & 46 & 73.0 & 1 & 1.6 & 63 & 52.07 & \\
\hline Tinggi & 13 & 22.4 & 45 & 77.6 & 0 & 0 & 58 & 47.93 & \\
\hline Total & 29 & 24.0 & 91 & 75.2 & 1 & 0.8 & 121 & 100 & \\
\hline
\end{tabular}

Berdasarkan tabel 4.7 dijelaskan bahwa hasil analisis dengan uji chi square pada sub variabel motivasi intrinsik dihubungkan dengan hasil belajar menunjukkan bahwa 50 orang $(71.4 \%)$ mahasiswa yang memiliki motivasi intrinsik yang rendah memperoleh hasil belajar sangat memuaskan dan ada 1 orang (1.4\%) yang memiliki motivasi rendah dan memperoleh hasil belajar cumlaude. Sedangkan diantara mahasiswa yang memiliki motivasi intrinsik yang tinggi, terdapat 10 orang (19.6\%) memperoleh hasil belajar memuaskan. Hasil uji statistik diperoleh nilai $\mathrm{p}=0.418$, maka dapat disimpulkan bahwa tidak ada hubungan atara motivasi intrinsik untuk ekstrinsik yang rendah memperoleh hasil belajar sangat memuaskan. Sedangkan diantara mahasiswa yang memiliki motivasi ekstrinsik yang tinggi, terdapat 1 orang (1.5\%) memperoleh hasil belajar cumlaude, namun ada 14 orang $(21.5 \%)$ mahasiswa memiliki motivasi ekstrinsik yang tinggi memperoleh hasil belajar memuaskan. Hasil uji statistik diperoleh nilai $\mathrm{p}=0.532$, maka dapat disimpulkan bahwa tidak ada hubungan atara motivasi ekstrinsik untuk menjadi perawat profesional dengan hasil belajar bagi Mahasiswa Semester V Akper Pemkab Belu TA 2014/2015. Artinya Ho gagal ditolak 
Secara keseluruhan pada bagian variabel motivasi yang dihubungkan dengan hasil belajar menunjukkan bahwa terdapat 1 orang (1.6\%) mahasiswa yang memiliki motivasi yang rendah memperoleh hasil belajar cumlaude dan ada 46 orang $(73.0 \%)$ mahasiswa yang memiliki motivasi rendah memperoleh hasil belajar sangat memuaskan. Sedangkan diantara mahasiswa yang memiliki motivasi yang tinggi, ada 13 orang (22.4\%) yang memperoleh hasil belajar memuaskan. Hasil uji statistik diperoleh nilai $\mathrm{p}=0.572$, maka dapat disimpulkan bahwa tidak ada hubungan atara motivasi untuk menjadi perawat profesional dengan hasil belajar bagi Mahasiswa Semester V Akper Pemkab Belu TA 2014/2015. Artinya Ho gagal ditolak.

\section{PEMBAHASAN}

Setelah melalui analisa data penelitian bivariat, dapat dilihat bahwa nilai $\mathrm{P}$ Value lebih dari 0,05 atau bermakna tidak terdapat hubungan antara motivasi untuk menjadi perawat profesional dengan hasil belajar pada mahasiswa. Hasil analisa data ini bertolak belakang dengan hipotesis penelitian yang menyatakan bahwa terdapat hubungan antara motivasi untuk menjadi perawat profesional dengan hasil belajar mahasiswa.

Motivasi merupakan salah satu aspek yang mempengaruhi hasil belajar, baik itu motivasi intrinsik maupun ekstrinsik. Menurut J. Guilbert dalam Nursalam (2008), aspek-aspek yang mempengaruhi hasil belajar terbagi atas fisiologis dan psikologis. Motivasi merupakan salah satu aspek yang tergabung dalam aspek psikologis. Menurut teori tersebut jelas terlihat bahwa seharusnya motivasi memiliki hubungan dengan hasil belajar, namun pada hasil penelitiam ini membuktikan bahwa tidak terdapat hubungan antara motivasi dengan hasil belajar.

Terdapat penelitian tentang motivasi untuk menjadi perawat dengan hasil belajar yang memiliki kesamaaan dengan penelitian ini. Penelitian tersebut dilakukan oleh Nadzirudin,dkk (2007), Sri (2010), Sujatmiko (2009). Ketiga peneliti ini meneliti pada mahasiswa keperawatan. Hasil penelitian mereka tidak mendukung hasil penelitian ini. Ketiga peneliti tersebut meneliti tentang motivasi untuk menjadi perawat dengan hasil belajar mahasiswa dan mendapat hasil bahwa terdapat hubungan antara motivasi untuk menjadi perawat dengan hasil belajar, apabila motivasi tinggi maka hasil yang diraih tinggi, dan motivasi untuk menjadi perawat memiliki kontribusi terhadap hasil belajar.

Tentu hasil penelitian tersebut sangat bertolak belakang dengan hasil penelitian ini yang menyatakan tidak terdapat hubungan antara motivasi untuk menjadi perawat profesional dengan hasil belajar yang diraih mahasiswa. Namun bukan hanya motivasi yang memiliki hubungan dengan hasil belajar. Selain motivasi, kemungkinan hal ini disebabkan karena faktor lain yang berhubungan, seperti Intelegent Quetion, Emotional Quetion, Spiritual Quetion, Creativity Quetion, Adversity Quetion, kelengkapan anggota tubuh, minat, bakat, motif, materi, lingkungan, instrument.

Selain faktor-faktor lain yang telah disebutkan, peneliti melihat terdapat responden dengan motivasi yang rendah untuk menjadi perawat profesional memiliki hasil belajar yang tinggi. Hal ini mungkin dipengaruhi oleh komitmen dari mahasiswa itu sendiri untuk mendapatkan nilai yang 
tinggi, bukan karena motivasi mereka untuk menjadi perawat profesional, mereka hanya belajar untuk mendapatkan nilai yang tinggi. Pada saat melaksanakan praktikum pun mereka melakukan praktek dengan baik bukan karena motivasi untuk menjadi perawat profesional yang tinggi, namun karena ingin memiliki hasil belajar yang tinggi. Faktor-faktor tersebut memiliki kemungkinan untuk memengaruhi hasil belajar pada mahasiswa Akper Pemkab Belu.
Mahasiswa Semester V Akper Pemkab Belu TA 2014/2015.

\section{SARAN}

\section{a. Untuk Institusi}

Memfasilitasi untuk mendesiminasikan hasil penelitian ini agar semakin banyak mahasiswa yang mengetahui tentang hubungan antara motivasi mahasiswa untuk menjadi perawat profesional dengan hasil belajar.

\section{KESIMPULAN}

Berdasarkan hasil penelitian univariat dan bivariat, dapat disimpulkan bahwa terdapat $70 \quad(57.9 \%)$ mahasiswa Akper Belu yang memiliki motivasi intrinsik yang rendah untuk menjadi perawat professional dan terdapat 64 (52.9\%) mahasiswa Akper Belu yang memiliki motivasi ekstrinsik yang tinggintuk Peneliti selanjutnya untuk menjadi perawat professional, terdapat pula $63(52.1 \%)$ Mahasiswa Semester V Akper Pemkab Belu TA 2014/2015 yang memiliki motivasi rendah untuk menjadi perawat professional namun ada 58 ( $47.9 \%)$ Mahasiswa memiliki motivasi tinggi untuk menjadi perawat professional, ada pun hasil belajar pada mahasiswa semester V Akper Pemkab Belu TA 2014/2015 menunjukkan data bahwa rentang IP 2,00-2,75 dengan predikat sangat memuaskan merupakan rentang IP dengan jumlah mahasiswa terbanyak,yakni 117 $(96,7 \%)$. Dan rentang IP yang memiliki persentase terendah yaitu $1(0,8 \%)$ adalah mahasiswa memiliki rentang IP 3,51-4,00 dengan predikat cumlaude. Berdasarkan hasil analisis SPSS dapat disimpulkan bahwa tidak ada hubungan antara motivasi intrinsik, ekstrinsik, dan motvasi pada
Peneliti selanjutnya disarankan meneliti faktor-faktor lain yang berhubungan dengan hasil belajar, selain motivasi untuk menjadi perawat professional, termasuk diantaranya komitmen mahasiswa untuk mendapatkan hasil belajar yang baik, serta pengaruh dari setiap variabel motivasi terhadap hasil belajar.

\section{KEPUSTAKAAN}

Budiarto, E. (2002). Biostatistika
untuk Kedokteran dan
Kesehatan Masyarakat.
Jakarta: EGC


Dmyati, Mudjiono. (2006). Belajar dan Pembelajaran. Jakarta: Rineka Cipta

Kusnanto. (2003). Pengantar Profesi dan Keperawatan Profesional. Jakarta:EGC

Notoatmojo,Soekidjo. (2001). Ilmu Perilaku Kesehatan. Jakarta: Rineka Cipta

Nursalam. (2003). Metodologi Penelitian Ilmu Keperawatan . Jakarta: salemba Medika

Nursalam. (2013). Metodologi Penelitian Keperwatan edisi 3. Jakarta: Salemba Medika

Nugroho,Febtian (2011). Hubungan Motivasi Untuk menjadi Perawat Profesional dengan Hasil Belajar akademik Mahasiswa Diploma Fakultas Keperawatan UPH Jakarta.

Sardiman. (2001). Interaksi dan Motivasi Belajar-Mengajar. Jakarta: Grafindo Persada

Uno, Hamsah. (2007). Teori Motivasi dan Pengukurannya. Jakarta: Bumi Aksara 